Prepared in cooperation with the Federal Emergency Management Agency

Estimated Magnitudes and Recurrence Intervals of Peak Flows on the Mousam and Little Ossipee Rivers for the Flood of April 2007 in Southern Maine

Open-File Report 2007-1146 
THIS PAGE INTENTIONALLY LEFT BLANK 


\section{Estimated Magnitudes and Recurrence Intervals of Peak Flows on the Mousam and Little Ossipee Rivers for the Flood of April 2007 in Southern Maine}

By Glenn A. Hodgkins, Gregory J. Stewart, Timothy A. Cohn, and

Robert W. Dudley

Prepared in cooperation with the Federal Emergency Management Agency

Open-File Report 2007-1146 


\section{U.S. Department of the Interior DIRK KEMPTHORNE, Secretary}

\section{U.S. Geological Survey \\ Mark D. Myers, Director}

U.S. Geological Survey, Reston, Virginia: 2007

For product and ordering information:

World Wide Web: http://www.usgs.gov/pubprod

Telephone: 1-888-ASK-USGS

For more information on the USGS - the Federal source for science about the Earth, its natural and living resources, natural hazards, and the environment:

World Wide Web: http://www.usgs.gov

Telephone: 1-888-ASK-USGS

Any use of trade, product, or firm names is for descriptive purposes only and does not imply endorsement by the U.S. Government.

Although this report is in the public domain, permission must be secured from the individual copyright owners to reproduce any copyrighted materials contained within this report.

Suggested citation:

Hodgkins, G.A., Stewart, G.J., Cohn, T.A., and Dudley, R.W., 2007, Estimated magnitudes and recurrence intervals of peak flows on the Mousam and Little Ossipee Rivers for the flood of April 2007 in southern Maine: U.S. Geological Survey Open-File Report 2007-1146, 5 p. 


\section{Contents}

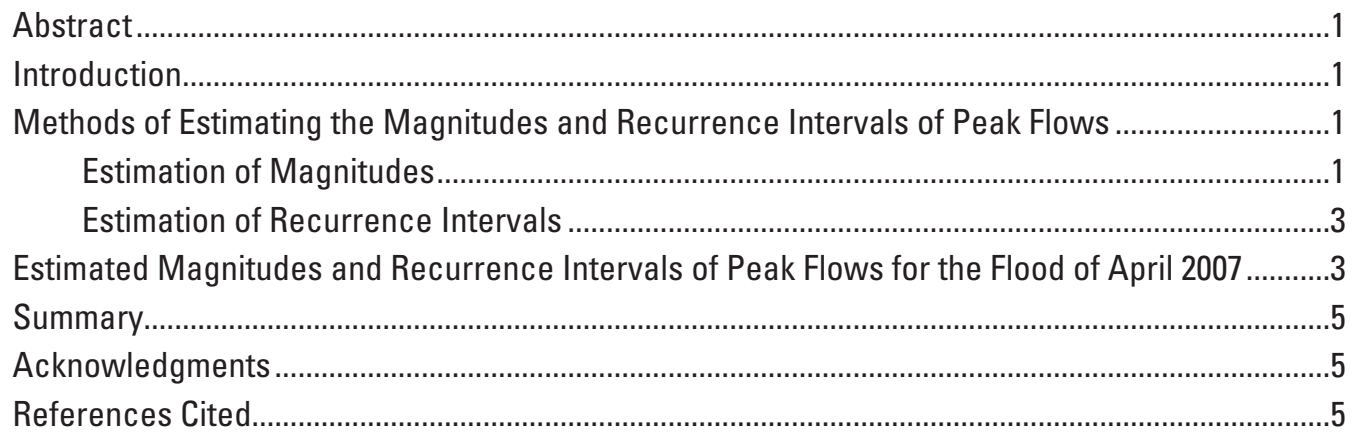

\section{Figure}

1. Map showing Mousam River and Little Ossipee River Basins in southern Maine and data-collection locations

\section{Tables}

1. Estimated peak flows for selected recurrence intervals, Mousam River near West Kennebunk (USGS station number 01069500).

2. Estimated peak flows for selected recurrence intervals, Little Ossipee River near South Limington (USGS station number 01066500). . .4

3. Estimated peak flows and recurrence intervals for flood of April 2007............................4 


\section{Conversion Factors}

\section{Inch/Pound to SI}

\begin{tabular}{|c|c|c|}
\hline Multiply & By & To obtain \\
\hline \multicolumn{3}{|c|}{ Length } \\
\hline inch (in.) & 2.54 & centimeter $(\mathrm{cm})$ \\
\hline inch (in.) & 25.4 & millimeter $(\mathrm{mm})$ \\
\hline foot (ft) & 0.3048 & meter $(\mathrm{m})$ \\
\hline \multicolumn{3}{|c|}{ Area } \\
\hline square mile $\left(\mathrm{mi}^{2}\right)$ & 259.0 & hectare (ha) \\
\hline square mile $\left(\mathrm{mi}^{2}\right)$ & 2.590 & square kilometer $\left(\mathrm{km}^{2}\right)$ \\
\hline \multicolumn{3}{|c|}{ Volume } \\
\hline cubic foot $\left(\mathrm{ft}^{3}\right)$ & 0.02832 & cubic meter $\left(\mathrm{m}^{3}\right)$ \\
\hline \multicolumn{3}{|c|}{ Flow rate } \\
\hline cubic foot per second $\left(\mathrm{ft}^{3} / \mathrm{s}\right)$ & 0.02832 & cubic meter per second $\left(\mathrm{m}^{3} / \mathrm{s}\right)$ \\
\hline
\end{tabular}




\title{
Estimated Magnitudes and Recurrence Intervals of Peak Flows on the Mousam and Little Ossipee Rivers for the Flood of April 2007 in Southern Maine
}

\author{
By Glenn A. Hodgkins, Gregory J. Stewart, Timothy A. Cohn, and Robert W. Dudley
}

\begin{abstract}
Large amounts of rain fell on southern Maine from the afternoon of April 15, 2007, to the afternoon of April 16, 2007, causing substantial damage to houses, roads, and culverts. This report provides an estimate of the peak flows on two rivers in southern Maine- the Mousam River and the Little Ossipee River-because of their severe flooding. The April 2007 estimated peak flow of $9,230 \mathrm{ft}^{3} / \mathrm{s}$ at the Mousam River near West Kennebunk had a recurrence interval between 100 and 500 years; 95-percent confidence limits for this flow ranged from 25 years to greater than 500 years. The April 2007 estimated peak flow of $8,220 \mathrm{ft}^{3} / \mathrm{s}$ at the Little Ossipee River near South Limington had a recurrence interval between 100 and 500 years; 95-percent confidence limits for this flow ranged from 50 years to greater than 500 years.
\end{abstract}

\section{Introduction}

Flood-related data is useful for many purposes. For example, the Federal Emergency Management Agency (FEMA) and Maine Emergency Management Agency (MEMA) need timely information on the magnitudes and recurrence intervals of floods to help respond to flood damage. Peak-flow magnitudes are used to help delineate floodplain boundaries for land-use planning, and to design bridges, culverts, and other structures in the floodplain. Flood data are also used for scientific purposes, including the study of the effects of climate changes and land-use changes on hydrologic regimes, which in turn affect ecosystems.

On April 9, 2007, a thin, wet snowpack covered the ground in the Mousam and Little Ossipee River Basins. Snowpack was measured at four locations in or near the basins on April 9 (West Kennebunk, Newfield, Hollis, Cornish, fig. 1) as part of the Maine Cooperative Snow Survey program. Snowpack depths ranged from 2.4 to 5.3 in. and had an equivalent water content of 0.8 to $1.5 \mathrm{in}$. There was no snowpack at the sites in West Kennebunk, Newfield, and Hollis on April 19 (no data available for Cornish) (Maine Cooperative Snow Survey,
2007). A storm on April 12 and 13 may have changed the equivalent water content in the snowpack prior to the April 2007 flood, either by adding to the snowpack or by melting and then replacing the snowpack (Thomas Hawley, National Weather Service, written commun., 2007).

Most of the rainfall that caused the April 2007 flood occurred from the afternoon of April 15, 2007, to the afternoon of April 16, 2007. Maximum 24-hour total precipitation at continuous-record precipitation gages in Sanford, Hollis, and Cornish (fig. 1) were 7.58 in., 4.97 in., (Thomas Hawley, National Weather Service, Gray, Maine) and 4.60 in., respectively (Cornish data from USGS continuous-rainfall gage).

This report presents results of a preliminary study conducted by the U.S. Geological Survey (USGS) to collect, compute, and compile flood-related data for the Mousam and Little Ossipee Rivers, which were substantially impacted by the storm. Estimates are presented of the magnitudes and associated recurrence intervals of peak flows for the Mousam River and the Little Ossipee River, for the flood of April 2007. Although the Mousam River Basin has reservoirs with sufficient storage capacity to potentially affect the magnitude of peak flows, the actual effect of reservoirs on April 2007 peak flows was not analyzed in this report.

\section{Methods of Estimating the Magnitudes and Recurrence Intervals of Peak Flows}

\section{Estimation of Magnitudes}

The 2007 peak flow at the Mousam River near West Kennebunk was estimated from surveyed April 2007 high watermarks by extension of the historical rating curve (the relation between river height and flow). This is believed to be a reasonable approach based on the stability and type of the river height/flow control for high flows at this location. 


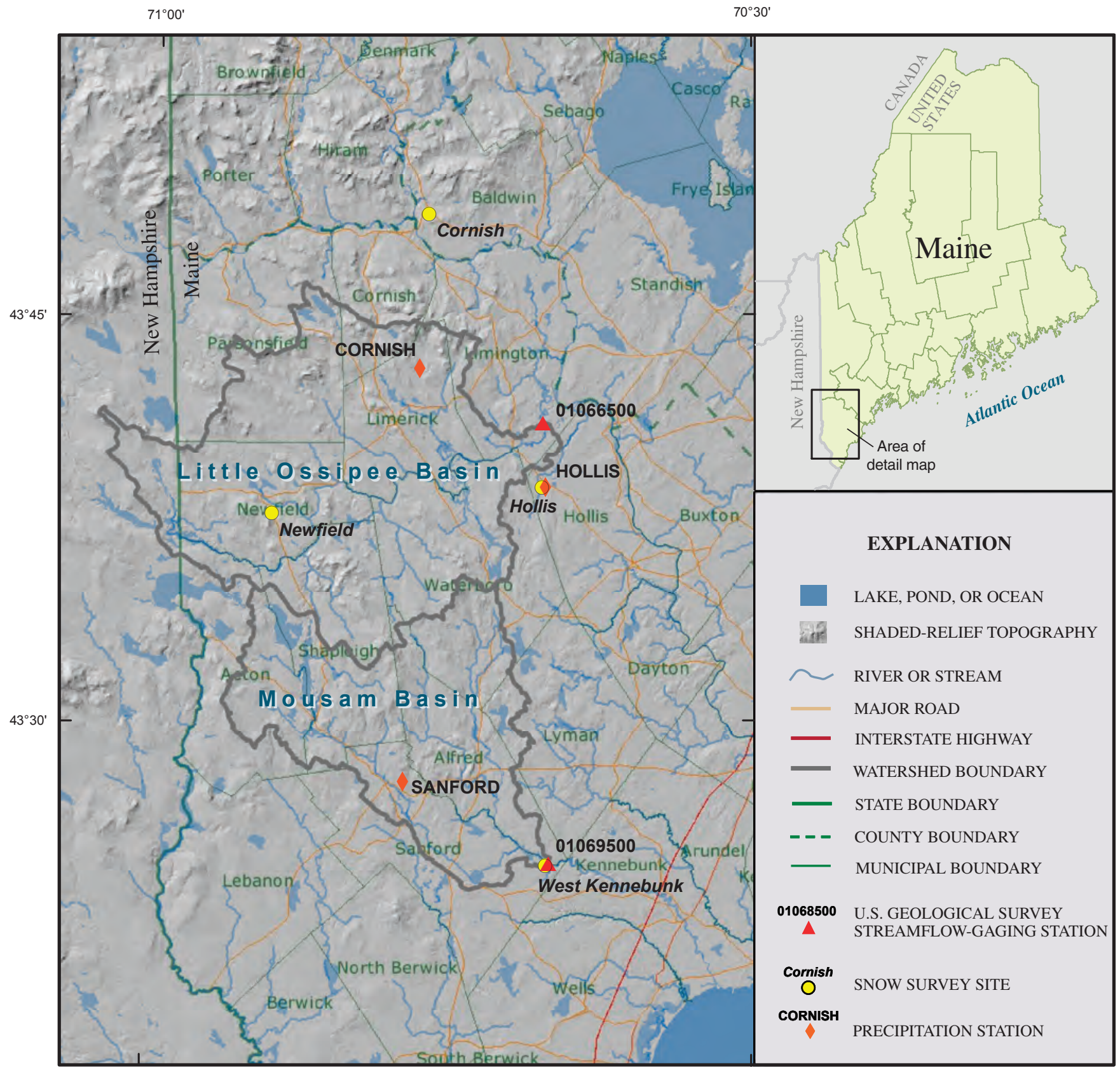

Base from USGS and Maine Office of GIS digitial files NAD83 UTM Zone 19

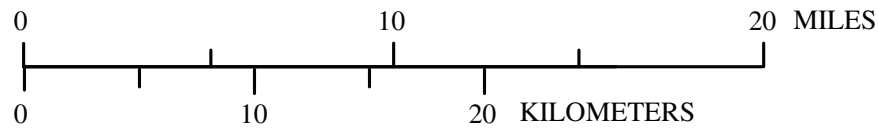

Figure 1. Mousam River and Little Ossipee River Basins in southern Maine and data-collection locations. 
The 2007 peak flow at the Little Ossipee River near South Limington was estimated using surveyed April 2007 high watermarks and hydraulic principles for contracted openings (Matthai, 1967) at the Sand Pond Road bridge. The geometry of the channel and bridge was defined by field surveys. The geometric data were entered in the U.S. Army Corps of Engineers (USACE) step-backwater computer program HEC-RAS (U.S. Army Corps of Engineers, 2004). The one-dimensional steady-flow water-surface profile computation component of HEC-RAS was used in the analysis. Boundary conditions and energy-loss parameters, including channel roughness and contraction and expansion coefficients, were measured and(or) estimated in the field and further adjusted during calibration of the model. The model was fully calibrated to match 2007 flood high-watermark elevations at the upstream approach and downstream exit sections of the bridge to within $\pm 0.01 \mathrm{ft}$ of the highest-quality high-watermark elevations. In addition to the calibrated 2007 flood flow, a range of flows (with recurrence intervals from 2 years to 500 years) were modeled as part of the calibration to test that model functionality was well conditioned.

\section{Estimation of Recurrence Intervals}

The recurrence interval is the statistically computed average period of time between peak flows that are greater than, or equal to, a specified magnitude. For example, the 50 -year peak flow is the flow that would be exceeded or equaled, on long-term average, once in 50 years. This does not imply that flooding will happen at regular intervals. Two 50 -year peak flows could be experienced in 2 consecutive years. Conversely, a 50-year peak flow might not be experienced for 100 years. The reciprocal of the recurrence interval is the annual exceedance probability, which is the probability that a given peak flow will be exceeded or equaled in any given year. For example, the annual exceedance probability of the 50-year peak flow is 0.02 . In other words, there is a 2-percent chance that the 50-year peak flow will be exceeded or equaled in any given year.

The U.S. Geological Survey (USGS) collected continuous streamflow data on the Mousam River near West Kennebunk (USGS station number 01069500) from October 1939 to September 1984 and on the Little Ossipee River near South Limington (station number 01066500) from August 1940 to October 1982 (fig. 1). Annual peak-flow data for these stations were obtained from the USGS National Water Information System (U.S. Geological Survey, 2007).

For the Mousam River, the largest peak flow recorded from 1939 to 1984 was 4,020 ft³ $/ \mathrm{s}$ on March 20, 1983. Known peak flows occurred outside of the period of continuous record; on October 22, 1996, the peak flow was 3,600 ft $3 / \mathrm{s}$ and on May 15, 2006, the peak flow was 6,100 ft $3 / \mathrm{s}$. For the Little Ossipee River, the largest peak flow recorded from 1940 to 1982 was 5,760 ft³/s on March 15, 1977; on March 19, 1936, the peak flow was $8,530 \mathrm{ft}^{3} / \mathrm{s}$; and on October 22, 1996, the peak flow was $5,800 \mathrm{ft}^{3} / \mathrm{s}$.
Peak flows for selected recurrence intervals were estimated for this report by use of the Expected Moments Algorithm (EMA) (Cohn and others, 1997; Cohn and others, 2001; Griffis and others, 2004). EMA is a generalization of the procedures in Bulletin 17B (Interagency Advisory Committee on Water Data, 1982) and was designed to better accommodate historical peak-flow data — known peak flows outside the period of continuous streamflow data collection. Although the procedures in Bulletin 17B can employ historical data, EMA makes more efficient use of historical data and the EMA confidence intervals are more accurate than the ones given in Bulletin 17B. Peak flows from the April 2007 flood were used in the calculations.

Regional information was not used to estimate the peak flows for the Mousam River because of its substantial historical flow regulation. Reservoirs (Square Pond, Mousam Lake, Estes Lake) above the USGS streamflow-gaging station near West Kennebunk were believed in 1984 to have a combined capacity of about 700,000,000 ft ${ }^{3}$ (Haskell and others, 1985). Flow-storage capacity above the station could affect recorded peak flows by more than 10 percent (Hodgkins, 1999; Benson, 1962).

Regional information was used to compute a weighted skew for the Little Ossipee River following the procedures in Griffis and others (2004). The generalized skew used at this site was 0.029 with a standard error of 0.297 (Hodgkins, 1999). Regional regression equations were not used to weight the at-site data; Hodgkins (1999) found that the weighted estimates for the 2-year to 500-year peak flows differed by less than 3 percent from station estimates for the Little Ossipee River.

\section{Estimated Magnitudes and Recurrence Intervals of Peak Flows for the Flood of April 2007}

The estimated April 2007 peak flow for the Mousam River near West Kennebunk was 9,230 ft 3 /s. The largest previously known peak flow from 1939 to 1984, 1996, and 2006 was 6,100 ft $3 / \mathrm{s}$ on May 15, 2006. The computed April 2007 peak flow for the Little Ossipee River near South Limington was $8,220 \mathrm{ft}^{3} / \mathrm{s}$. The largest known peak flow from 1936, 1940 to 1982 , and 1996 was 8,530 ft³ $/ \mathrm{s}$ on March 19, 1936.

Estimated peak flows for the Mousam River and Little Ossipee River and their associated recurrence intervals are shown in tables 1 and 2, along with 95-percent confidence intervals. The April 2007 flood at the Mousam River near West Kennebunk had a recurrence interval between 100 and 500 years; 95 -percent confidence limits ranged from 25 years to greater than 500 years. The April 2007 flood at the Little Ossipee River near South Limington had a recurrence interval between 100 and 500 years; 95 -percent confidence limits ranged from 50 years to greater than 500 years (table 3 ). 
Table 1. Estimated peak flows for selected recurrence intervals, Mousam River near West Kennebunk (USGS station number 01069500).

[USGS, U.S. Geological Survey; ftºs, cubic feet per second; confidence intervals are 95-percent confidence intervals]

\begin{tabular}{cccc}
\hline $\begin{array}{c}\text { Recurrence interval } \\
\text { (years) }\end{array}$ & $\begin{array}{r}\text { Estimated peak flow } \\
\left(\mathbf{f t}^{3} / \mathbf{s}\right)\end{array}$ & $\begin{array}{r}\text { Lower confidence interval } \\
\left(\mathbf{f t}^{3} / \mathbf{s}\right)\end{array}$ & $\begin{array}{c}\text { Upper confidence interval } \\
\left(\mathbf{f t}^{\mathbf{3}} / \mathbf{s}\right)\end{array}$ \\
\hline 2 & 1,390 & 1,120 & 1,650 \\
5 & 2,230 & 1,750 & 2,890 \\
10 & 3,010 & 2,370 & 4,400 \\
25 & 4,340 & 3,210 & 9,830 \\
50 & 5,630 & 3,930 & 18,300 \\
100 & 7,240 & 4,730 & 32,500 \\
500 & 12,700 & 6,990 & 126,000 \\
\hline
\end{tabular}

Table 2. Estimated peak flows for selected recurrence intervals, Little Ossipee River near South Limington (USGS station number 01066500).

[USGS, U.S. Geological Survey; $\mathrm{ft}^{3} / \mathrm{s}$, cubic feet per second; confidence intervals are 95-percent confidence intervals]

\begin{tabular}{cccc}
\hline $\begin{array}{c}\text { Recurrence interval } \\
\text { (years) }\end{array}$ & $\begin{array}{c}\text { Estimated peak flow } \\
(\mathbf{f t} \mathbf{t} / \mathbf{s})\end{array}$ & $\begin{array}{c}\text { Lower confidence interval } \\
(\mathbf{f t} \mathbf{t} / \mathbf{s})\end{array}$ & $\begin{array}{c}\text { Upper confidence interval } \\
(\mathbf{f t} \mathbf{s} / \mathbf{s})\end{array}$ \\
\hline 2 & 2,090 & 1,760 & 2,480 \\
5 & 3,330 & 2,770 & 4,080 \\
10 & 4,280 & 3,490 & 5,450 \\
25 & 5,640 & 4,430 & 7,700 \\
50 & 6,770 & 5,160 & 9,850 \\
100 & 7,990 & 5,910 & 12,500 \\
500 & 11,300 & 7,690 & 21,400 \\
\hline
\end{tabular}

Table 3. Estimated peak flows and recurrence intervals for flood of April 2007.

[USGS, U.S. Geological Survey; $\mathrm{mi}^{2}$, square miles; $\mathrm{ft}^{3} / \mathrm{s}$, cubic feet per second; confidence intervals are 95-percent confidence intervals]

\begin{tabular}{lccccc}
\hline \multicolumn{1}{c}{ River name } & $\begin{array}{c}\text { USGS station } \\
\text { number }\end{array}$ & $\begin{array}{c}\text { Drainage } \\
\text { area } \\
\left(\mathbf{m i}^{2}\right)\end{array}$ & $\begin{array}{c}\text { Estimated } \\
\text { peak flow } \\
\left(\mathbf{f t}^{3} \mathbf{s}\right)\end{array}$ & $\begin{array}{c}\text { Recurrence } \\
\text { interval } \\
\text { (years) }\end{array}$ & $\begin{array}{c}\text { Confidence intervals } \\
\text { (years) }\end{array}$ \\
\hline Mousam River near West Kennebunk, Maine & 01069500 & 99.0 & 9,230 & 100 to 500 & 25 to greater than 500 \\
Little Ossipee River near South Limington, Maine & 01066500 & 168 & 8,220 & 100 to $500 \quad 50$ to greater than 500 \\
\hline
\end{tabular}




\section{Summary}

The Federal Emergency Management Agency (FEMA) and Maine Emergency Management Agency (MEMA) need timely information on the magnitude and recurrence intervals of floods to help respond to flood damage. Large amounts of rain fell on southern Maine in April 2007, causing substantial damage to houses, roads, and culverts. Most of the rainfall occurred from the afternoon of April 15, 2007, to the afternoon of April 16, 2007; maximum 24-hour total precipitation at continuous-record precipitation gages in Sanford, Hollis, and Cornish was 7.58 in., 4.97 in., and 4.60 in., respectively.

The resulting April 2007 peak flow at the Mousam River near West Kennebunk was estimated from surveyed flood marks by extension of the historical rating curve (the relation between river height and flow). The peak flow at the Little Ossipee River near South Limington was estimated using surveyed flood marks and hydraulic principles for contracted openings.

The estimated April 2007 peak flow for the Mousam River near West Kennebunk was 9,230 ft³. The largest known peak flow from 1939 to 1984, 1996, and 2006 was $6,100 \mathrm{ft}^{3} / \mathrm{s}$ on May 15, 2006. The estimated April 2007 peak flow for the Little Ossipee River near South Limington was $8,220 \mathrm{ft}^{3} / \mathrm{s}$. The largest known peak flow from 1936, 1940 to 1982, and 1996 was 8,530 $\mathrm{ft}^{3} / \mathrm{s}$ on March 19, 1936.

Peak flows for selected recurrence intervals were estimated for this report by use of the Expected Moments Algorithm (EMA). Recurrence intervals are the statistically computed long-term-average period of time between peak flows that are greater than, or equal to, a specified magnitude.

The April 2007 estimated peak flow at the Mousam River near West Kennebunk had a recurrence interval between 100 and 500 years; 95-percent confidence limits ranged from 25 years to greater than 500 years. The April 2007 flood at the Little Ossipee River near South Limington had a recurrence interval between 100 and 500 years; 95 -percent confidence limits ranged from 50 years to greater than 500 years.

\section{Acknowledgments}

Thomas Hawley of the National Weather Service in Gray, Maine, provided most of the meteorological data analyzed in this report. Joshua Kempf and Nicholas Stasulis of the USGS Maine Water Science Center collected a substantial amount of field data that were required for this report.

\section{References Cited}

Benson, M.A., 1962, Factors influencing the occurrence of floods in a humid region of diverse terrain: U.S. Geological Survey Water-Supply Paper 1580-B, 64 p.

Cohn, T., Lane, W.L., and Stedinger, J.R., 2001, Confidence intervals for EMA flood quantile estimates: Water Resources Research, v. 37, no. 8, p. 1695-1706.

Cohn, T., Lane, W.L., and Baier, W.G., 1997, An algorithm for computing moments-based flood estimates when historical flood information is available: Water Resources Research, v. 33, no. 9, p. 2089-2096.

Griffis, V.W., Stedinger, J.R., and Cohn, T.A., 2004, LP3 quantile estimators with regional skew information and low outlier adjustments: Water Resources Research, v. 40, doi:10.1029/2003WR002697.

Haskell, C.R., Bartlett, W.P., Higgins, W.B., and Nichols, W.J., 1985, Water resources data, Maine, water year 1984: U.S. Geological Survey Water-Data Report ME-84-1, 144 p.

Hodgkins, G.A., 1999, Estimating the magnitude of peak flows in Maine for selected recurrence intervals: U.S. Geological Survey Water-Resources Investigations Report 99-4008, 45 p.

Interagency Advisory Committee on Water Data, 1982, Guidelines for determining flood flow frequency-Bulletin 17-B of the Hydrology Subcommittee, March 1982 (revised and corrected), 28 p. and appendices.

Maine Cooperative Snow Survey, 2007, accessed April 28, 2007, at http://www.maine.gov/mema/weather/snow.htm

Matthai, 1967, Measurement of peak discharge at width contractions by indirect methods: Techniques of WaterResources Investigations of the U.S. Geological Survey, book 3, chap. A4, $44 \mathrm{p}$.

U.S. Army Corps of Engineers, 2004, HEC-RAS River Analysis System Version 3.1.2: Hydrologic Engineering Center, accessed April 29, 2007, at http://www.hec.usace.army.milh

U.S. Geological Survey, 2007, National Water Information System, accessed April 28, 2007, at http://waterdata.usgs. gov/me/nwis/sw 
THIS PAGE INTENTIONALLY LEFT BLANK 
Prepared by Publications Service Center 1

For more information concerning the research in this report, contact: Robert M. Lent, Director

U.S. Geological Survey

Maine Water Science Center

196 Whitten Road

Augusta, ME 04330

or visit our Web site at:

http://me.water.usgs.gov 


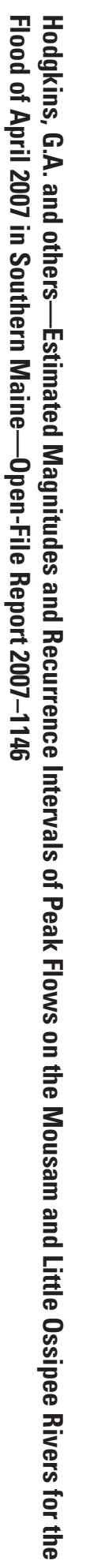

9 Printed on recycled paper 